tions were given to a lapidary at Amsterdam to reduce the diamond to the perfect form. It weighed 186 carats in the Exhibition, and was reduced to $103 \frac{1}{4}$ carats in the process of rubbing off the broken pieces. The same workman had since been engaged in cutting the "Star of the South," a very large diamond exhibited at the Paris Exhibition. Going through the interesting diamond cutting works the other day, at Amsterdam, he found about one thousand persons employed in cutting diamonds. The workmen were all of the Jewish persuasion. His friend, Professor Pole, was with him. A wheel was used during the process, and revolved at the rate of 800 times a minute; and could be regulated to any required speed. Nine-tenths of the workmen knew nothing of crystallography, and were only guided by long practice. He (Mr. Tennant) was grateful to Mr. Mitchell, not only for this lecture, but for the lectures which he had delivered to Mr. Tennant's students at King's College. It might be asked, of what use was this science to geology? What was geology? The science of crystallography formed part of the alphabet of mineralogy. The geologist had to be a palæontologist, a conchologist, a mineralogist, a chemist, and a botanist.

\title{
Ordinary Meeting, Monday, 3rd December, 1860.
}

The Rev. T. Wiltshire, M.A., F.G.S., President, in the Chair.

The following gentlemen were elected members of the Association :Rev. R. Bingham, M.A.; R. G. Clutton, Esq. ; and J. R. Markby, Esq.

The following donations were announced :-

"The Abstracts of the Proceedings of the Geological Society." By the Geological Society.

A series of Fifty species of Land and Fresh-water Shells, from the Tertiary Upper Deposits at Copford, in Essex. By J. Pickering, Esq.

J. Cumming, Esq., and R. Farmer, Esq., were, in accordance with Rule 30, elected to audit the Accounts at the Annual General Meeting, on January 7 th, 1861.

* See a paper on "Diamonds," by W. Pole, F.G.S., in Macmillan's Magazine, for January, 1861. 
The following papers were read :-

1.- "On a New Red Sandstone Quarry at Stourton, in Cheshire." By J. H. Mitchener, Esq.

An hour's sharp walking from Birkenhead, striking off through the village of Tranmere, will enable a tolerable pedestrian to arrive at a neatly-erected stone, placed on the highest of a range of hills, from which he may learn the precise number of feet he then happens to be standing above the river Mersey - a height, according to the authority of the Geological Survey of Great Britain, the most elevated in the county of Cheshire. Half a mile from this spot lies the village of Stourton, whose quarries supply the material for constructing the greater portion of the churches, chapels, and other public buildings of the north. The public road, on either side of which the stone is excavated, runs parallel with, and is constructed on, the anticlinal axis of the stratum, the beds sloping off to the right and left. A transverse section of the anticlinal ridge discovers an appearance somewhat singular and unusual, for the central and highest portion has all the appearance of stratification, yet in a perpendicular position, and at right angles to the dip of the true beds. After much patient investigation and actual experiment, it was shown by the late Dr. Buckland to be the result of pressure, consequent on the withdrawal of the upheaving force ; thereby subjecting the intervening mass to heat so intense, as to induce a laminated semblance to stratification.

The quarry to the left of the road exposes some fifty feet of the new red sandstone. The upper portion, about twenty feet in thickness, is of a dull red colour, from which the stratum takes its name. It is of a coarse texture, somewhat soft when first worked, but hardens on exposure to the atmosphere. Between this and the lighter-coloured stone below, and forming a line of demarcation between them, is a thin shale of not more than one inch in thickness. This narrow strip does not appear in any place to widen out. It can be detected and followed, in whatever part of the neighivourhood the stone is quarried, separating the darker from the lightercoloured bed. The latter is a fine-grained compact stone, of a pale yellow or cream tint. It is this stratum that is principally sought for building purposes. About thirty feet lies open to examination, though probably it attains to double that number in thickness.

In point of palæontological interest, the new red sandstone contrasts unfavourably with the rich fossilliferous beds of the period immediately 
succeeding; and Stourton Quarry can scarcely be quoted as an exception. The eye wanders up and down its lofty sandstone sides, but scans in vain the vast mass of rock for a solitary bivalve. Apparently, it is a sepulchre untenanted-a blank page in the rock-recorded history of our planet's former inhabitants. Not a fossil of any kind is visible, as if the period, being thoroughly ashamed of its population, had, by means of a ceaseless shifting of its grinding particles, so far succeeded in pulverizing their remains, as completely to obliterate all traces of their existence.

The thin shale before described has, to the utmost of its limited dimensions, compensated for the general dearth, and endeavoured to redeem the palæontological interest of the triassic. Here are found the only relics of the creatures in the shape of their foot-prints. Nearly all the impressions are of animals belonging to the order of Batrachians. The chubby foot of the Labyrinthodon (Labyrinthodon pachygnathus of Owen) is now becoming somewhat scarce at Stourton; the more elongated toes of the Cheirotherium of Professor Kaup are more frequently met with. In the full-grown animal of the latter species, the hind-foot of the largest specimen I have found has measured ten inches in length, and the step nearly two feet. The fore-foot is very small, as in all creatures of the toad kind. Some of the foot-prints are sharp and well defined, others deeper and less intelligible, indicating an unequal consistency in the condition of the mud, when traversed by the animals; in some parts sufficiently hard to resist the pressure of the font and admit of a sharp impression, in other places, by the foot sinking, little more is perceptible in the fossil than a confused hole. It is worthy of remark, these foot-prints, when discovered, and examined in situ, invariably point in the same direction. Unlike the wise men, however, who came from the east-judging from the position of the toes of the batrachians-they appear to have travelled from the opposite quarter.

On the slab immediately overlying the shale, capital casts of the impressions are found, which find their way into the various museums of the country.

By far the best specimen of the full-grown true Eabyrinthedon the writer has yet met with, might some little time since have been seen on the top of a pig-sty belonging to one of the workmen. No geologist that visited Stourton Quarry but was dragged up its steep and rugged sides to view this unique, scientific gem, in its rather inelegant setting. A sight of it 
seldom fails to elicit from the visitor an exclamation of surprise and delight, and stimulates an interest in the study, such as the more honoured and aristocratically-preserved slabs of the Bloomsbury, Jermyn Street, Liverpool, or Manchester Museums, in vain attempt to inspire.

It shows three consecutive foot-prints of the hind and fore-paws, with a length of stride of about eighteen inches. Being the upper slab, and consequently a cast, the impressions are in relief, and, from the sharpness of their outline, very suggestive.

With a pertinacity for which quarrymen are remarkable, the workmen adhere to the statement of occasionally also finding live toads in the solid stone. The impression left by the Cheirotherium is known to them by the cognomen of the "lady's foot," though a single glance determines it considerably more to resemble that of a hippopotamus.

The upper slabs, bearing the casts of the foot-prints, may be seen in blocks lying about the quarry in all directions. An examination of some of them would almost induce a belief the animals themselves entertained a determination to destroy the evidences of their trail. No sooner does one of these geological Indians appear to have crossed the bank and left a fair impression, than another, in attempting to plant his foot in the same hole, and but partially succeeding-and this not unfrequently further improved by a third, diametrically across the two-renders identification almost as hopeless a task as that of deciphering the cumeiform characters of a Nineveh relic. Patient investigation, however, will generally induce the slab to confess to a Rhynchosaurus and some smaller companions of the period.

In the year 1841 a gigantic fucoid was discovered in the same quarry, and stretched over the rock to a length of eighty feet and upwards. When we remember that sea-weeds are frequently met with in the Atlantic 200 feet in length-occasionally, by-the-bye, mistaken for and described as sea-serpents-we see nothing unreasonable in the supposition that this fossil fucoid may possibly be found to attain another eighty feet in the stone yet unquarried.

After a drawing had been executed by Mr. Cunningham, F.G.S., for the British Museum, and casts taken of various portions of the stem and branchlets, it was broken up, and but a comparatively small fragment remains for the inspection of the occasional visitor. Unfortunately for science, the tiny ones of the cottagers are particularly partial to dancing on 
this spot; and their little feet are rapidly obliterating the characters of the specimen, and robbing the district of one of its ornaments of geological interest.

Passing from the centre of the quarry, through a short tunnel and longer cutting, to its outer extremity, the stone gradually assumes a less compact and more friable appearance. This continues the further we retreat, until, on arriving at the edge of this primæval sandbank, evidences of the influence of our satellite in the far by-gone of the Triassic is recorded in the successive sweepings of beautifully-delineated tidal marks.

Hard by this spot an accumulation of general debris, including boulders and other water-worn fragments of rocks foreign to the locality, intermingled with ice-grooved blocks of sandstone rudely deposited on the side of a hill, give evidences of the passage of the northern drift. The hammer, hitherto an useless incumbrance, now finds ample employment in boulder chipping. Greenstones (whose nearest parent rock must be sought in Cumberland), granitic emigrations from Scotland, basalts of Arthur's Seat origin, and endiess chips of sundry old blocks of well-ascertained porphyries and serpentines, torn from their native beds by the irresistible influence of ice, carried away 300 miles from home-here commingle together to form a deposit of what may be designated twelve feet of utter confusion.

The district has received considerable attention from $\mathrm{Mr}$. Cunningham, F.G.S., and Professor Archer, Director of the Scottish Museums.

In concluding these fragmentary remarks, I would briefly acknowledge my obligations to the latter gentleman, in whose company I visited Stourton Quarry.

2. - "On Brickfields, Gravel Pits, Sand Pits, and Peat Beds, at Copford, Fisherton, West Hackney, Reculvers, and Kennet Valley." By J. Pickering, Esq., Vice.President.

In placing before you this evening a series of interesting and mostly minute shells, consisting of 50 species (viz., 35 land and 15 fresh-water, the names of which are annexed at the close of this paper)-discovered and collected by my respected friend, the late Mr. John Brown, of Stanway, in the Upper Tertiary Deposit, at Copford, in Essex-I regret my inability to give much more information respecting them, from personal knowledge, than their mere identification. With their exact position in situ I am not acquainted, since the beds whence they were obtained were 
never visited by me; nor did I ever procure a closer inspection of them than could be had from the windows of a railway train. The first and only opportunity offered me of viewing the locality was whilst travelling to Ipswich, when, just after the train had passed beyond Marks Tey station, the Copford brickfield was pointed out to me as lying a little to the right of the embankment. And yet, although I have seen so little of the place, considerable quantities of the shells have passed through my hands for examination, and many hours have been spent in separating and determining their species, by means of a bull's-eye condenser, a moderately strong lens, and a pair of small and delicate brass pliers.

And now, having imparted to you the extent of my own knowledge, or rather want of it, on the subject, I will give some extracts in reference to these beds, from a paper by Mr. Brown, on the Upper Tertiaries at Copford, read before the Geological Society of London, and printed in their "Quarterly Journal," Vol. VIII., p. 184.

"The Copford fresh-water beds have been for several years extensively excavated to obtain brick earth, which is procured from three extensive workings, hereafter referred to as the western, eastern, and southern sections, respectively. Other sections of these beds have been discovered by casual excavations, and by borings to the west and south of the brickfield. This brickfield is about half-a-mile N.W. of Stanway Church, and lies between the railway and the high road, occupying about five acres. The ground slopes from the high road northward, to the flat marshy ground, which is crossed by the railway embankment.

"Although the Copford deposit cannot boast of such a long and varied list of fossil mammalia as those of Grays and Clacton, it is richer in land and fresh-water mollusca; that of Clacton having produced about fifty species, and Grays about forty-five species, while Copford has afforded sixty-nine species, as far as investigations in these deposits have hitherto gone.

"Tha beds forming this deposit run in the following order, commencing at the surface:-

"1. Brown clay, with pebbles, \&c.

" 1 '. Brown sandy loam.

"2. Shell marl and ferruginous sand (furrowed surface), containing bones and shells.

“ 2 '. The same, passing into clay, rich in shells. 
"3. Vegetable bed, containing shells.

"4. Blue clay (brick earth) with bones and shells

" 4 '. Yellow clay, with ' race"

\} not laminated.

" 4 ". Yellow and blue clays, laminated.

“5. Grey sandy gravel, containing shells and drifted fossils.

" 5 '. Sandy gravel.

"In digging through the bed No. 4, the workmen met with a bed of sand and gravel (No. 5), with calcareous concretions, rounded chalk debris, flints-both rounded and angular, boulders of lias, and other rock fragments. This bed is very rich in fragments of ammonites, ostreoe, \&c., and organic remains (for the most part small) derived from the lias, oolite, greensand, gault, chalk, and tertiary formations, with land and freshwater shells.

"The bed No. 4 consists of blue clay, containing a large quantity of calcareous matter; it is about eleven feet in thickness, and its surface is un. dulated throughout. At the southern part of the eastern excavation this bed passes upwards into a yellow clay (No. 4'), six feet thick, with numerous small irregularly-rounded concretions of carbonate of lime ('race' of the workmen). In a section opened in the southern part of the field in 1836, and separated from the eastern section by a strip of ground that is not worked-consisting, probably, of bed No. 5, and forming, as it were, a ridge traversing the field from $F_{\text {. }}$ to $\mathrm{W}$.- -appears a yellow, sandy clay (No. 4"), laminated about ten feet thick, dipping to the south, and there passing into, and alternating with, similar clay of a blue colour. In this laminateü yellow clay are found numerous thin calcareous concretions, flat and irregular in shape, as well as a few of the roundish calcareous bodies above mentioned; the yellow clay rests on a sandy gravel (No. $5^{\prime}$ ), towards the surface it sometimes contains much chalk debris, and at places it is seen to pass upwards into an obscurely laminated brown loam. In the western part of this excavation (which is somewhat basin-shaped), the yellow clay laminæ vary in their dip from S. to S.E., and to nearly E. This laminated yellow and blue clay is, in my opinion, the same as the blue clay of the eastern and western sections; which latter is coextensive with the other beds hereafter mentioned, that occupy the site of what appears to have been an ancient fresh-water lake, being more than a mile in extent from east to west, and about three-quarters of a mile in a north and south direction. 
"The clay undergoes a process of puddling and washing, in a horsemill, preparatory to its being used in brickmaking; and from the debris of these washings various organic remains and rock fragments have been obtained, rolled fragments of chalk, rolled and angular flints, fragments of Kimmeridge clay, and minute fossils from the upper secondary rocks.

"I formerly noticed the occurrence of fragments of fresh-water shells in the upper part of the blue clay (No. 4), especially Valvata and opercula of Bithinia; on a recent exanination of portions of this bed, nine species of fresh-water shells, and three species of Foraminifera of existing forms were discerned.

"The shells are much more abundant in the upper part of the clay than below, which latter is mixed with siliceous sand, forruginous grains, minute fragments of chalk, and a few of the most common chalk Foraminifera, together with portions of Sphagnum.

"Bones of the elephant, stag, aurochs, bear, and beaver have been obtained from the blue clay.

"On this calcareous clay we have a very compact deposit of vegetable matter (No. 3), generally from three to twelve inches thick, but at the eastern section it increases southward to a thickness of six or seven feet. It is similar to peat, but not so inflammable, having a small portion of argillaceous matter distributed throughout its mass; it is often incorporated with the upper portion of the blue clay. In this bed have been found compressed branches of trees, and shells of Valvata piscinalis, and, in 1836, I found Cyclas rivicola in groups.

"Over this layer of vegetable matter there occurs a bed of shell marl, (No. 2), from one to six feet thick, which lies conformably on the undulatory surface of the blue clay, into which it sometimes sends down oblique veins (west section). This bed dips to the north with a slight angle (about $5^{\circ}$ ), and thins out towards the southern part of the brickfield. It varies considerably in its character throughout this area, sometimes consisting wholly of a white calcareous marl, having a chalky appearance, and sometimes of the latter, alternating with ferruginous sands, or passing into sand or clay. In the western excavation it is chiefly composed of white sand and shell fragments (Valvata piscinalis). In the first-named condition no shells or parts of shells have been found in it, although, most probably, it is wholly derived from the decomposition of accumulated remains of dead molluses. When it becomes sandy, how- 
ever, both broken and perfect shells are not rare; but when it passes into clay, the remains ot land and fresh-water molluses are abundantly found in a perfect state. In the light-coloured clay (No. 2'), into which the marl passes in one part of the eastern section, exposed in 1850 , thirty-two species have been found, of which two are extinct, viz., Helix incarnata? and Helix ruderata.

"In this marl the horn-core, and bones of ox, antlers of stag, and bones of elephant, have been met with.

"Overlying the white marl is an unstratified deposit of reddish-brown clay (No. 1), containing chalk nodules, rounded and angular flints, boulders of grey-wether, and other sandstones, limestones, conglomerates, and porphyritic rocks. This clay is from one to six feet thick, the greatest thickness occurring in the northern part of the field. To the south it passes over the limit of the marl beds, and rests on the yellow bed into which the blue clay or brick earth passes. No organic remains have been found in this brown clay excepting a molar tooth of a horse, and this was obtained near its junction with the white marl.

"At the western and northern parts of the field there is a superficial bed of peat, about one foot in thickness, with recent land and fresh-water sheils, many of which retain their epidermis.*

"Having thus described the Cupford deposits in detail, I would observe that the sandy gravel (No. 5) appears to me to belong to the till or bonlder clay; the blue clay or brick earth (No. 4) I have long regarded as a modification of that deposit, on account of its organic and mineral contents, which have originally been derived from a distance; and the brown clay, with boulders also (No. 1), certainly contains evidence of an origin identical with that of the boulder clay. The angular flints, and sandstone-boulders especially, scattered over the surface here, are similar to those of the till of the neighbouring parts of Essex. In the till, fossil remains have been found in great abundance.

"Finally, I wish to draw attention to the discovery of two extinct molluses (Helix ruderata and H. incarnata?) in the Copford marls-a fact of considerable importance in tstimating the relative age of this deposit; and I would observe, that not the least interesting phenomenou of the Copford fresl-water beds is the superposition of an upper member of

* This also occurs in the Peat-beds of the Kennet Valley.-J. 1. 
the local boulder formation (bed No. 1) on the shell marl, which latter with its subjacent clays, rests on an earlier member of this formationconditions clearly pointing out the age of the intercalated deposit. This seems to accord also with an analogous geological phenomenon in the cliffs of Eastern Norfolk and other localities, as noticed in Sir C. Lyell's ' Manual of Elementary Geology,' p. 127."

Having given these extracts from Mr. Brown's paper, I would state that I have two objects in laying this collection of the Pleistocene, or Upper Tertiary, land and fresh-water fossil shells before you. The first is, to call the attention of our young and uninitiated friends aud members to the importance of a careful examination of brickfields, sand-pits, gravelpits, and peat-beds; ugly places, truly, but by no means to be despised by geologists and fossil-hunters; although spots where, doubtless, very many persons would little expect to find fossils, especially in such abundance and good state of preservation. Indeed, they would tell you they had seen numerous brichfields and gravel-pits, but never noticed any fossils in them-for this reason, because they either did not look, or did not know how to look, for them. As an example of my meaning, let me mention that, some time since, a gentleman who was fond of angling, complaining one day of his bad sport, was asked by me to search for shells instead of fishes. He replied, "The labour would be of little use, inasmuch as there were no specimens of the kind in the stream, except a few river muscles (Unio and anodon) at the bottom; had there been others, he was convinced he must have seen them long ago." I assured him there were plenty, and, having instructed him how and where to look, we parted. In less than a week he returned, bearing - in triumph, and astonished at bis good fortune (good fortune in reality dependent upon himself)-a small box filled with living shells, amongst which was a rare variety of a species which had not hitherto fallen into my hands.

The same will apply to those persons who have visited numbers of brickfelds, gravel-pits, \&c., without seeing fossils. I do not imply that fossils are to be found in every brickfield and gravel-pit, \&c.; but at the same time I must tell you that Copford is not the only brickfield from whence fossils of the character just alluded to have been procured.

Mr. Prestwich, accompanied by Mr. Brown, explored Mr. Harding's brickfield, at Fisherton, near Salisbury; where they collected, together with mammalian remains, a quantity of land and fresh-water shells, of which [ 
was enabled to identify twenty-one species. An account of this brickfield can be seen in the "Journal of the Geological Society of London," Vol. XI., p. 101. I might mention several others of less importance.

In Mr. Hindle's gravel-pit, at West Hackney, Mr. Prestwich discovered at least twenty-three species of land and fresh-water shells; as these occurred in a rotten, and often fragmentary state, it is probable many more species may be found in the same neighbourhood. See "Journal of Geological Society of London," Vol. XI., p. 107.

In a sand-pit on Wear Farm, near the Reculvers, situated on the road from Chislet to the Reculvers, Mr. Prestuich met with a most interesting deposit, the account of which I cannot do better than recite to you in his own words, from the "Quarterly Journal of the Geological Society," for May, 1855. Vol. XI., p. 110.

"This deposit is exposed in two pits near Wear Farm (see Ordinance Map), on the road from Chislet to the Reculvers. The height of the ground above the level of the adjacent marsh, or of the sea, does not exceed 20 to 30 feet. The pit in a field to the east of the road offers the best section; it is as follows, in descending order:-1st, gravel, 3 to 8 feet; 2nd, sand, with laminated clay, 8 to 12 feet; 3rd, chalk. The shells occur principally in seams of fine gravel in the lower part of the section, where there is sand with seams of fine gravel; in a few spots only are they numerous. The greater portion of the sands and gravel are without shells. Entomostraca, however, appear to be more abundantly diffused, but still they occur chiefly in certain seams or layers.

"I found a few bones of large Mammals, some apparently belonging to the ox. The shells are in a good state of preservation, and consist of the following species, which have been examined and determined by $\mathrm{Mr}$. Pickering :-

"Bithinia tentaculata, Linn.

"Ancylus fluviatilis, Müll.

"Paludina, or Rissoa; very like the one found at Grays.

"Cyrena consobrina, Caill.

"(C. trigonula, Wood).

"Opercular valves of Balanus.

" This list, although short, is of considerable interest; for here we find the Grays, or Nile Cyrena, together with two more distinctly fresh-water shells, associated with the distinetly marine genus, the Balanus. The 
opercular valves of this Cirriped were found in the fine gravel filling the interior of a Cyrena. The small Paludinæ and the Cyrenæ abound in places. Imperfect traces of vegetable remains occur in some thin seams of clay subordinate to the mass of sand and fine gravel. The general character of the organic remains indicates a local deposit, accumulated on the spot, and in comparatively tranquil waters.

"The fossiliferous bed is overlaid by a mass of gravel rubble and brick earth, varying in thickness from three to eight feet.

"As well as the few specimens will allow us to judge, this deposit may be correlated with the one at Clacton, on the opposite Essex coast, and will probably yield on further examination a far more important series of pleistocene fossils than those here enumerated, which were procured during two very short visits.

"Of the microscopic fossils in the deposit, the Entomostraca comprise, according to Mr. Rupert Jones, three forms-the first is very abundant, the other two very rare:-Candona torosa, Jones; Cypris gibba, Ramd., and a minute undeterminable form.

"There is also among the minute organisms picked out from these sands one rizopod-a globulina.

"The Candona torosa is a minute bivalved crustacean, inhabiting the brackish water-ditches near Gravesend. It occurs also plentifully in the Grays deposit, in company with other recent and some extinct(?) Entromostraca. Cypris gibba is a recent form, very common in fresh-water ponds.

"The Foraminifer (globulina), by its presence in the deposit in question, may be regarded as evidence of the at least brackish-water character of the Wear Farm sands. Mr. Pickering, who first discovered the recent specimens of C. torosa in the Gravesend ditches, found also a Rosalinalike Foraminifer associated with them - a parallel to the above.

"The valves of the Entomostraca are sometimes separate, sometimes united. The sand and fine gravel in which these pleistocene fossils occur, frequently contain also numerous minute chalk fossils, such as cytherellae, bulimina, rosalina, and cristellaria," \&e.

While on this subject, I cannot conclude without calling your attentiou to the Peat Beds of the Kennet Valley, in the vicinity of Newbury, Berks; from which I identified between fifty and sixty species of land and freshwater shells, collected by my friend Mr. Rupert Jones, of the Geologicial 
Society, who has paid much attention to the geology of that district, and which were described by him in a lecture delivered to the members of the Literary and Scientific Institution, in the Mansion House, at Newbury, March, 1854; from the Appendix to which published lecture, at page 40, I will, if you please, take an extract:-

" The peat fields near Newbury, when examined, present the following series of deposits :-

"1. Alluvium, or superficial soil.

“2. Shell marl, called 'malm,' varying from oue inch to eight feet in thickness, sometimes seamed with peat; occasionally wanting. On the 'marsh,' at Newbury, it is lefe in small hillocks, barely coated with the sward. Hard, ovoidal, concentric masses of concreted marl, of various dimensions, up to the size of a man's head, occur here and there in this deposit; generally near the present course of the river. These concretions, like the marl itself, are wholly composed of the more or less decomposed shells of fresh-water molluses, such as bithinia, limnaus, cyclas, \&c.

"3. Peat, varying from a thin film to more than ten feet; sometimes it is only a peaty earth, and often interrupted by seans of marl.

"4. Shell marl; argillaceous, very tough, about one or two feet thick, and very general.

“5. Gravel.

"There is more peat and less 'malm" in the Speen Merc than in Ham Marsh.

"The bones of mammalian animals have been frequently found in these peat beds, as they generally are in similar deposits. These remains are usually met with in the lower marl (4, of the above list), and apparently are more plentiful towards the edge of the valley.

"The following list comprises the best known of these fossils, from the neighbourhood of Newbury:-ancient ox, short-horned ox, roebuck, red deer, horse, boar, wolf, otter, bear, beaver, and water-rat.

"In the peat there are found :-

"Fir cones, fir bark and wood, birch bark and wood, hazel-nuts, moss, \&c.; also fifty-three species of land and fresh-water shells, identified by my friend, Mr. J. Pickering, from a collection made in 1842 ; as well as three or more species of cypris (minute bivalved crustaceans), and quantities of gyrogonites, or the seed-vessels of the common water-plant, the Chara. 
"Numerous miscellaneous articles belonging to the 'historic period" have been met with in the peat fields; but the exact circumstances under which they have been found, and their respective positions in the several beds, have not been carefully recorded.

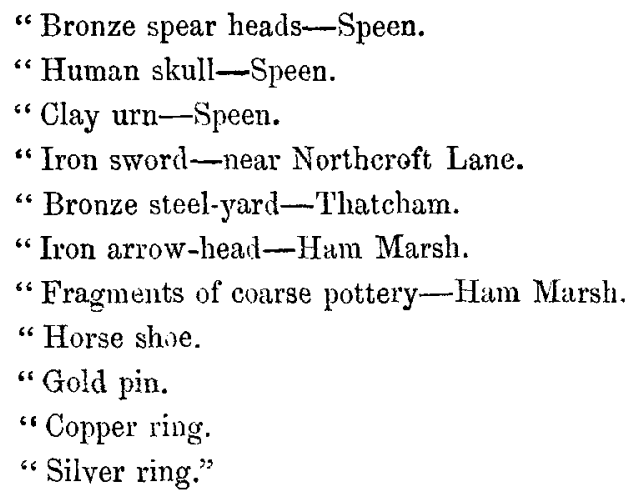

Having thus dwelt upon some of the facts connected with brickfields and gravel-pits, \&c., I beg to present to the Museum of this Association a typical series of the shells of the land and fresh-water mollusca of the pleistocene, or upper tertiary strata of this country; both derived from a deposit where they are more numerous, and in a more perfect state of preservation, than any that have come under my notice, and also discovered and collected by that zealons geologis, the sincere friend of, and the first benefactor to, this Association-the late Mr. John Brown, of Stanway.

The following list gives the names of these shells, the nomenclature being that of Gray's edition of Turton's Manual, 1840:-

\section{LAND SHELLS.}

1. Helix nemoralis, Liunæus .. R.C.

2. $"$ arbustorum $" \ldots .$,

s. " hispida $", \quad \ldots . c$,

4. " conciana, Jeffreys .... "

5. " pulchella, Müller ....",

6. " fulva $"$..... R.C.

7. " rufescens, Penuant ..... C.

8. " aculeata, Müller ...... ",

9. " lamellata, Jeffreys .... ,"

10. " sericea, Draparnaua ...R.R.

11. " lapicida, Linnsus .... "

12. " Ova of Helix ....... ,

13. Zonites rotundatus, Miailur . A.B.
14. Zonites radiatulus, Alder .... R.C.

15. " nitidulus, Draparnaud "

10. " pygmaus ", R.R.

17. " crystallinus, Mibller .. C.

18. " cellarias " .. R.C.

19. " alliarius, Mitler ..." "

20. " lucidus, Draparnaud . "

21. Azeca tridens, Pultney .....R.R.

22. Zua lubrica, Müller $\ldots \ldots \ldots$ C.

23. Pupa marginata, Draparnaud R.C.

24. " umbilicata " "

25. " Anglica, Ferussac ....R.R.

26. Vertigo palustris, Turton .... ,

$\therefore 7$. " pusilla, Müller ..... R. R. C. 
Lave SHersus (continued).

29. Vertigo edentula, Draparnaud R.R.

29. " pygmæa " R.C.

30. " augustior, Jeffreys .. "

31. " alpestris, Turton ...R.R.

32. " substriata, Jeffreys .. "

33. Clausilia nigricans, Maton and

Rackett ..........R.C.

34. Caryehium minimum, Mialler A.B.

35. Aome fusca, Montagu....... ,

Fresh-water Shells.

36. Succinea putris, Linnæus .... C.

3\%. Linnæus truncatulus, Mḯller,

3R. " pereger ........R.R.

Explanation.-A.B., abundant; C., common; R.C., rather common; R.R., rather rare; $R$. rare.
Fresh-water Shelus (continued). 39. Linnæus palustris, Linnæus R.R.

40. Aplexus hypnorum " "

41. Planorbis spirorbis "

42. " contortus " R.R.

43. " marginatus, Drap. . R.

44, $\quad, \quad$ allus, Müller ...R.R.

45. $\quad$ vortex, Linnæus .. R.

46. Bithinia tentaculata and operculum, Linnzus ......... ,

47. Valvata piscinalis, Müller ....R.R.

48. " cristata " ... "

49. Pisidium obtusale, Pfeiffer .. C.

50. " pusillum, Turton .. "

I hope on a subsequent occasion to have the pleasure of contributing a cullection of the shells from the "Grays," and some other tertiary forma. tions; trusting, in the interim, that some of our members, who feel interested in tertiary fossils, will neither shut their eyes nor look in the wrong direction, when in the vicinity of brickfields, sancl or gravel-pits; where, if the men are at work, it will be found that the price of a piut or two of beer, if judiciously bestowed, will often produce great results. I trust also that those gentlemen, when successful, will not forget this Association, but will favour their brother members with some account of their explorations and a sight of their findings.

A discussion followed the reading of the paper, in which the President, Professor Tennant, Mr. Prestwich, Mr. Wetherell, Mr. Cumning, and other gentlemen took part.

Annual General Meeting, Monday, January 7th, 1861.

The Rev. Thomas Wiltshire, M.A., F.G.S., President, in the Chair.

The Secretary read the Amnual Report of the Committee, as follows:-

\section{REPORT.}

The Committee of the Geologists' Association, whilst presenting their Second Annual Report, have great pleasure in congratulating the meeting 